studies in the U.S. (See $A S A$ News, Vol. XIV, No. 4, Oct/Dec 1981. See also Special Announcements in this issue).

10 December, 1981

Dear Mr. Sklar:

Your 10 November 1981 letter to Major General Richard X. Larkin has been referred to me for reply. I succeeded him as Deputy Director of the Defense Intelligence Agency.

Our academic research support program was announced publicly in the 27 August 1981 Commerce Business Daily. There was nothing covert about our approach, and there is nothing covert in our purpose. We openly solicited statements of interest and qualification for academic research support of our program. We identified the Defense Intelligence Agency as the solicitor. We stated our interest in "unclassified, publishable research" on various aspects of various world regions, Africa being only one of them.

As for your Association's 1976 resolution, we have no intention of seeking, enlisting, or employing scholars for "clandestine intelligence operations." The African Studies Association holds no monopoly on concern about any academic relationship with an intelligence agency. We too are aware of and sensitive to that concern, and its ramifications.

As you know, participation in our program is optional. If a scholar or educational institution does not wish to take part in the program, he/she or it can ignore our solicitation, and say so publicily if so desired. Some Africa Study Center directors have said publicly they will not participate in our program. That is their prerogative. Meanwhile, numerous other scholars and academic institutions have evinced interest in our effort.

We value scholarship's contributions to the national understanding of developments at home and abroad. The importance of scholarly views as a factor in the national awareness of such developments, and indeed in national policy considerations, is unchallenged. We neither intend to compromise such national assets nor to jeopardize scholarly or academic credibility and integrity. There is a wealth of knowledge about the world abroad in the American academic community. We want to widen our perspective, and scholars' perspectives, on that world. We seek scholarly help in our attempt, but only on an open, unclassified, voluntary basis.

We believe our program will succeed. We think it can contribute not only to a better understanding of the world, but indeed may benefit various peoples and nations. Our program envisions serious, unclassified, scholarly research on topics of interest and concern to many states, the results of which would be available to them for their possible help and use.

We would welcome the assistance of the African Studies Association in this effort.

Sincerely
E. A. Burkhalter, Jr.
Rear Admiral, USN
Acting Director
Defense Intelligence Agency
Washington, DC

Sklar replied:

Dear Admiral Burkhalter:

Thank you for your reply to my letter of concern about the effects of your agency's new program to support academic research in several regions of the world, including 
Africa. Be assured that our Board of Directors will take your cogent explanation of the program fully into account when we discuss it at our Spring meeting. Our members will note with satisfaction your disavowal of any intent to enlist or employ scholars in "clandestine intelligence operations." I wish to commend your affirmation of that very important principle.

However, the dangers that we perceive in your new program produce grave concern despite its open, public, and unclassified nature. The dangers arise from the very fact that university-based research in the African studies field will be funded by the Defense Intelligence Agency.

The basic issues which have been identified in our exchange of letters relate to the credibility and integrity of American-based scholarship in the African studies field. I do appreciate your disavowal of intention to "compromise" or "jeopardize" either the credibility or the integrity of American university-based scholarship in Africa. Yet it is likely that each of these values will be undermined by the acceptance of support from your agency by university-based scholars.

Let me put the matter plainly. The Defense Intelligence Agency is primarily concerned with military applications of information and analysis. Its ultimate objective is the effective deployment of military force to accomplish American national purposes. For this reason, I view your agency's proposal to fund university-based research as an unwise action which would compromise the credibility and integrity of Africanist scholarship. These qualities have largely been the product of a process which ensures the independence of academic research and publication from national political aims.

American-based scholarship on all regions of the world is a great national resource. The national intelligence community is perfectly free to make use of scholarly resources by normal means. But my colleagues and I are deeply concerned that a direct patron-client relationship between an intelligence agency and segments of the academic community might erode the value of scholarly research as a national and international resource by compromising its independence.

I will report our correspondence to the Board of Directors of the African Studies Association for its consideration.

Sincerely, Richard L. Sklar President

\section{In the Case of Professor Wamba-dia-Wamba Kazu:}

Ed. note: The following was sent in response to the Professor's arrest in Zaire. See Special Announcements in this issue.

His Excellency Mobutu Sese Seko

1 February, 1982

President of the Republic of Zaire

Kinshasa, Zaire

Dear Mr. President:

I write to express deep concern on the part of many members of the academic community about recent reports of the detention and maltreatment of Professor Wamba-diaWamba Kazu, a historian at the University of Dar es Salaam.

It has been widely reported that Professor Wamba is being held in prison, without trial, in Zaire. His colleagues in many countries are anxious to ensure the protection of his 